\title{
Erratum: a consensus based template for reporting of pre-hospital major incident medical management
}

\author{
Sabina Fattah ${ }^{1,2^{*}}$, Marius Rehn ${ }^{1,2,3,4}$, David Lockey ${ }^{5,6}$, Julian Thompson ${ }^{6}$, Hans Morten Lossius ${ }^{1,2,3}$, Torben Wisborg ${ }^{2,7,8}$ \\ and The Major Incidence Reporting Collaborators
}

\section{Erratum}

After the publication of our article "A consensus based template for reporting of pre-hospital major incident medical management" Scand J Trauma Resusc Emerg Med 2013, 22:5, we noticed that The Major Incident Reporting Collaborators were not included as authors. They have now been added at the end of the author list. The group consists of Gareth Davies, Michel Debacker, Erik Frischknecht Christensen, Juhana Hallikainen, Troels Martin Hansen, Jorine Juffermans, Per Kulling, Vidar Magnusson, Jannicke Mellin-Olsen, Kai Milke, Anders Ruter, Stephen JM Sollid, Wolfgang Voelckel.

Authors' information

The Major Incidence Reporting Collaborators: Gareth Davies, Michel Debacker, Erik Frischknecht Christensen, Juhana Hallikainen, Troels Martin Hansen, Jorine Juffermans, Per Kulling, Vidar Magnusson, Jannicke Mellin-Olsen, Kai Milke, Anders Rüter, Stephen JM Sollid, Wolfgang Voelckel.

\section{Author details}

${ }^{1}$ Department of Research and Development, Norwegian Air Ambulance Foundation, Drøbak, Norway. ${ }^{2}$ Anaesthesia and Critical Care Research Group, Faculty of Health Sciences, University of Tromsø, Tromsø, Norway. ${ }^{3}$ Field of Pre-hospital Critical Care, Network of Medical Sciences, University of Stavanger, Stavanger, Norway. ${ }^{4}$ Department of Anesthesiology and Intensive Care, Akershus University Hospital, Lørenskog, Norway. ${ }^{5}$ School of Clinical Sciences, University of Bristol, Bristol, UK. '6ondon's Air Ambulance, The Helipad, Royal London Hospital, Whitechapel, London, UK. ${ }^{7}$ Department of Anaesthesiology and Intensive Care, Hammerfest Hospital, Finnmark Health Trust, Hammerfest, Norway. ${ }^{8}$ Norwegian Trauma Competency Service, Oslo University Hospital, Oslo, Norway.

\footnotetext{
* Correspondence: sabina.fattah@norskluftambulanse.no

'Department of Research and Development, Norwegian Air Ambulance

Foundation, Drøbak, Norway

${ }^{2}$ Anaesthesia and Critical Care Research Group, Faculty of Health Sciences, University of Troms $\varnothing$, Troms $\varnothing$, Norway

Full list of author information is available at the end of the article
}

Received: 15 July 2014 Accepted: 23 July 2014

Published online: 06 September 2014

\section{doi:10.1186/s13049-014-0042-6}

Cite this article as: Fattah et al.: Erratum: a consensus based template for reporting of pre-hospital major incident medical management. Scandinavian Journal of Trauma, Resuscitation and Emergency Medicine 2014 22:42

\author{
Submit your next manuscript to BioMed Central \\ and take full advantage of: \\ - Convenient online submission \\ - Thorough peer review \\ - No space constraints or color figure charges \\ - Immediate publication on acceptance \\ - Inclusion in PubMed, CAS, Scopus and Google Scholar \\ - Research which is freely available for redistribution
}

Submit your manuscript at

www.biomedcentral.com/submit

() Biomed Central

\section{() Biomed Central}

(c) 2014 Fattah et al.; licensee BioMed Central Ltd. This is an Open Access article distributed under the terms of the Creative Commons Attribution License (http://creativecommons.org/licenses/by/4.0), which permits unrestricted use, distribution, and reproduction in any medium, provided the original work is properly credited. The Creative Commons Public Domain Dedication waiver (http://creativecommons.org/publicdomain/zero/1.0/) applies to the data made available in this article, unless otherwise stated. 